\title{
Influence of agricultural extension activities on tick control among cattle on family dairy farms in the southeast Brazil
}

\author{
Fernanda Calvo Duarte ${ }^{1, *}$ (D) https://orcid.org/0000-0003-3983-9615 \\ Luiz Carlos Roma Junior² (D) https://orcid.org/0000-0002-0019-2538 \\ Marcelo Luz Santos' (D) https://orcid.org/0000-0001-6037-2568 \\ Leonardo Costa Fiorini ${ }^{1}$ (D) https://orcid.org/0000-0002-1466-9202 \\ Márcia Cristina Mendes' (D) https://orcid.org/0000-0002-5533-2921 \\ 1. Instituto Biológico - Centro de Pesquisa em Sanidade Animal - São Paulo (SP), Brazil. \\ 2. Instituto de Zootecnia - Centro de Pesquisa em Bovinos de Leite - Nova Odessa (SP), Brazil. \\ *Corresponding author: fernanda.duarte@sp.gov.br
}

\begin{abstract}
The aim of the present study was to evaluate the resistance of tick populations on 16 family farms that were members of the agricultural producers' cooperative of the São Pedro region of the state of São Paulo (COOPAMSP). Bioassays were conducted on nine commercial products in 2018 and 2019. Their active agents were as follows: deltamethrin, amitraz, cypermethrin + chlorpyrifos + citronella, cypermethrin + chlorpyrifos + fenthion, cypermethrin + chlorpyrifos + piperonyl butoxide, dichlorvos + chlorpyrifos, cypermethrin, chlorfenvinphos + dichlorvos, and ivermectin. On some farms, a larval packet test (LPT) was also performed. Overall, four acaricides presented mean efficacy greater than $89 \%$, among which two were associations of pyrethroids + organophosphates and two were associations of organophosphates + organophosphates. Deltamethrin, cypermethrin and ivermectin presented mean efficacy lower than $50 \%$. In the bioassays using the LPT, all five farms showed resistance to diazinon, while only one farm presented resistance to cypermethrin. The results were handed over to each farmer with appropriate guidance for treatments. This study demonstrated that the important points to be implemented related directly to use control strategies, based on direct assistance for farmers and diagnosis of tick population sensitivities.
\end{abstract}

Keywords: rural extension; Rhipicephalus (Boophilus) microplus; resistance.

\section{INTRODUCTION}

Rhipicephalus (Boophilus) microplus is one of the main ectoparasites of major health and economic impact for cattle-rearing worldwide. It inhabits tropical and subtropical countries, including Brazil. It is also an important vector for Babesia spp. and Anaplasma marginale, which cause babesiosis and anaplasmosis, respectively (GUGLIELMONE et al., 2010; GUGLIELMONE; NAVA, 2014). Ticks cause direct skin lesions and injuries in their hosts by means of hematophagy, and this gives rise to an environment that is ideal for attracting flies that cause myiasis (RECK et al., 2014). The losses caused by R. microplus are of the order of 3.24 billion dollars per year (GRISI et al., 2014).

The chemical groups organophosphates, pyrethroids, formamidines, macrocyclic lactones, fipronil and fluazuron are commonly used for controlling R. microplus in Brazil. Since the end of the 20th century, there have been reports of resistance to all these products. In a review conducted by HIGA et al. (2016), occurrences of the resistance of $R$. microplus in 15 regions of Brazil were listed. According to KOLLER et al. (2019), the greatest concentration of reports of resistance was in the central-southern region of the country, especially in the state of Rio Grande do Sul, where resistance to all chemical classes was present, including among associations of classes.

According to LE GALL et al. (2018), knowledge of resistance mechanisms may aid in seeking new strategies to mitigate resistance. These authors also reported that $\mathrm{ABC}$ transporters, which are proteins in the family of esterases, glutathione S-transferase (GST) and cytochrome P450, play an important role in the elimination of chemical molecules

Received: Sept 28, 2020. Accepted: Oct 31, 2021

Associate Editor: Silvia Galleti

Peer Review History: Double-blind Peer Review. 
from the organism of ticks (BAFFI et al., 2008; COSSÍO-BAYÚGAR et al., 2018; FEYEREISEN et al. 2015; HEMINGWAY et al., 2004; ROSARIO-CRUZ, 2009).

To effect rational management of resistance, it is firstly essential to detect this phenomenon, through monitoring and containment of resistant populations, with the aim of diminishing the costs and environmental damage (HIGA et al., 2016; KLAFKE et al., 2017; MENDES et al., 2001). Performing in vitro immersion bioassays on engorged females once a year provides data that may indicate the presence of resistance to commercial acaricides. At the same time, this may aid in making better decisions towards implementing effective treatment (GASPAR et al., 2018). Thus, these bioassays can be considered a tool for use on dairy farms.

According to ARAÚJO (2007), agricultural extension comprises the mission of using educational methods to transfer and disseminate technology and useful sustainable methods for work, production and commercialization to farmers. Thus, people implementing extension actions are the key element in this process and all the attention of the extension system needs to be concentrated on these individuals. The results that can be expected largely depend on these individuals' actions (PETTAN, 2005).

The aim of the present study was to evaluate the resistance of tick populations on family dairy farms that received agricultural extension actions relating to tick control and to the problem of resistance to acaricides that are available on the market.

\section{MATERIAL AND METHODS}

\section{Farms and location}

This experiment was conducted on 16 family farms that were members of the agricultural producers' cooperative of the São Pedro region of the state of São Paulo (COOPAMSP). The São Pedro region is located in the Piracicaba mesoregion of the state of São Paulo. These farms were participating in a technical assistance program for milk production through the Sustainable Rural Development Coordination (CDRS) office (CDRS/CATI), in Piracicaba.

This region has a climate of type Aw (tropical climate with a winter dry season), according to the KÖPPEN; GEIGER (1928) classification. It is at an altitude of $550 \mathrm{~m}$, with an annual mean temperature of $21.9^{\circ} \mathrm{C}$ and annual mean precipitation of $1307.5 \mathrm{~mm}$ (CEPAGRI, 2018).

\section{Collection of tick samples}

All the collections were performed in the summers of 2018 and 2019. On eight of the farms, two collections were performed (2018 and 2019), while on the other eight farms only one collection was performed. On five of the latter eight farms, collection was performed in 2018. The number of ticks per collection was approximately 100 engorged females.

After collection, these ticks were stored in 500-mL plastic flasks. The flasks were identified with the name and address of the farm and were stored in the isothermal boxes. They were then sent to the Animal Parasitology Laboratory of the Instituto Biológico.

Over a 14-day period before the scheduled collection day, the herds did not receive any treatment with acaricides.

\section{Bioassays}

\section{In vitro immersion test on engorged adult females}

In the laboratory, the engorged females were washed in distilled water, dried and divided into groups of ten, which were then weighed. Following this, they were immersed in commercial acaricides for $5 \mathrm{~min}$. After immersion, they were dried and laced on Petri dishes that were properly identified, and these were kept in a biochemical oxygen demand (BOD) chamber at a temperature of $28{ }^{\circ} \mathrm{C}$ and humidity of $80 \%$, for oviposition to take place. Fifteen days after oviposition, the eggs were removed, weighed and placed in assay tubes that were identified and closed using dampened absorbent cotton. After another 15 days, the percentage hatching of larvae was determined. The efficacy of the products was calculated as described by DRUMMOND et al. (1973). 
Bioassays were performed using nine commercial products in which the active agents were as follows: deltamethrin, amitraz, cypermethrin + chlorpyrifos + citronella, cypermethrin + chlorpyrifos + fenthion, cypermethrin + chlorpyrifos + piperonyl butoxide, dichlorvos + chlorpyrifos, cypermethrin, chlorfenvinphos + dichlorvos, and ivermectin. The $\mathrm{f}$ irst five of these products were tested both in 2018 and in 2019, on eight farms. For seven farms, only one test was performed (five in 2018 and two in 2019). Three of these products (cypermethrin, chlorfenvinphos + dichlorvos, and ivermectin) were only tested on 10 farms, in 2019. The products with the active agents dichlorvos + chlorpyrifos and cypermethrin were only tested on 13 farms, in 2018.

\section{Larval packet test (LPT)}

Larval packet tests (LPTs) were performed on larvae from ticks collected on five farms. One of these farms did not present sufficient ticks for the immersion test. The LPT used the active agents cypermethrin and diazinon to characterize the phenotypic resistance to the chemical groups pyrethroids and organophosphates, respectively.

Filter papers Whatman No. $1(85 \times 75 \mathrm{~mm})$ were impregnated with a volume of $0.67 \mathrm{~mL}$ containing the following concentrations of the active agents, using acetone as the solvent: $0.05,0.1,0.2,0.4,0.6,0.8,1.2,1.6,2.4 \mathrm{and} 3.2 \mu \mathrm{g} \cdot \mathrm{cm}^{-2}$ for diazinon; and 1.6, 6.4, 25.6, 102.4 and $409.6 \mu \mathrm{g} \cdot \mathrm{cm}^{-2}$ for cypermethrin. The control groups were exposed to filter paper that had only been impregnated with the solvent. The tests were performed in triplicate.

On the test days, the filter papers were taken out of the refrigerator, folded in the middle and sealed with metal clips on each side to form packets. Approximately 100 tick larvae were transferred to each packet using a brush. The packets were sealed with a third clip at the top and were incubated in a BOD chamber at $28^{\circ} \mathrm{C}$ and relative humidity of $80 \%$, for $24 \mathrm{~h}$. The packets with the larvae were then opened and inverted over a piece of white filter paper so that the dead larvae would fall out. The packets were then closed again and placed in a freezer $\left(-20^{\circ} \mathrm{C}\right)$ until the survivors also died. The larval mortality rate was determined by counting the total numbers of dead and live individuals. The mortality data were analyzed using the Probit model in the POLO-PC software (LEORA SOFTWARE, 1987).

\section{Dissemination of technology}

Between 2017 and 2019, three meetings were held to disseminate technical knowledge regarding the biology, ecology and strategic control of cattle ticks. These meetings were held in the evenings, at the main building of the cooperative, and the farmers were free to attend. The first meeting was in September 2017 and had the sole aim of presenting the topic of strategic control of ectoparasites and explaining the importance of tests for choosing the product to be used for control measures. At subsequent meetings, the results from the tests conducted on the farms were handed over to the farm owners and discussed with them, with guidance regarding treatments.

\section{RESULTS}

The efficacy results obtained from each farm were handed over to the farmers in person. The farmers were advised to only use acaricides that presented efficacy greater than $90 \%$ (Table 1). Information regarding time intervals between treatments and the correct methods for applying each product was also provided.

Among the efficacy results from the five acaricides that were only tested with tick samples from farms on which the immersion test was done both in 2018 and in 2019, the following points presented in Table 1 and Figures 1 and 2 can be highlighted:

- On farm "A", only the active agent cypermethrin + chlorpyrifos + piperonyl butoxide presented diminished efficacy, going from $100 \%$ (2018) to $59 \%$ (2019);

- On farm "D", the three associations of pyrethroid (PI) + organophosphate (OF) maintained $100 \%$ efficacy in both years;

- On five farms, the product cypermethrin + chlorpyrifos + citronella presented $100 \%$ efficacy in both years, and this was also seen on three farms regarding the formulation cypermethrin + chlorpyrifos + fenthion;

- Two associations of PI+OF (cypermethrin + chlorpyrifos + citronella and cypermethrin + chlorpyrifos + fenthion) presented mean efficacy of $100 \%$ in 2018 with reductions of $9.7 \%$ and $29.6 \%$ respectively in 2019 . The first of these was the only commercial product with mean efficacy greater than $90 \%$ in 2019 (Fig. 1);

- The mean efficacy of the pyrethroid deltamethrin was $29.1 \%$ (standard deviation of $32.5 \%$ ) in 2018 and $21.8 \%$ (standard deviation of 20.6) in 2019; Amitraz presented mean efficacy of 84.5\% in 2018 and $71.5 \%$ in 2019 (Fig. 1). Percentage mean efficacy of five acaricides on samples of the tick R. microplus from eight farms (A-H) in the São Pedro region of the state of São Paulo, in 2018 and 2019. 
Farm A

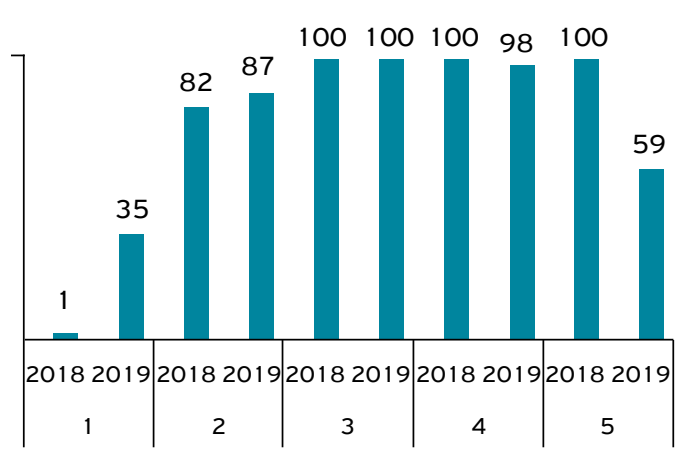

Farm C

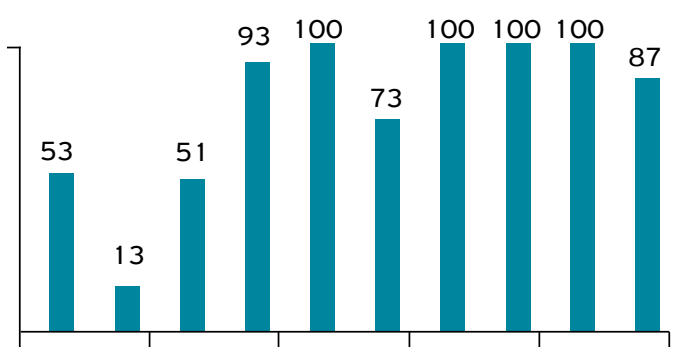

2018201920182019201820192018201920182019

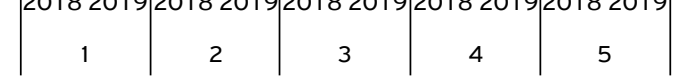

Farm E

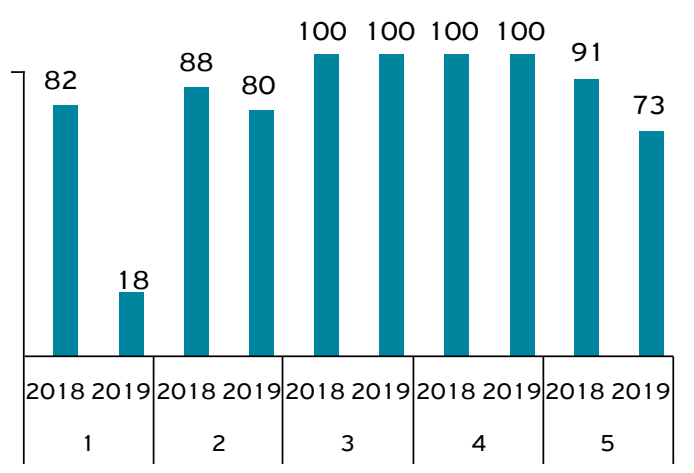

Farm G

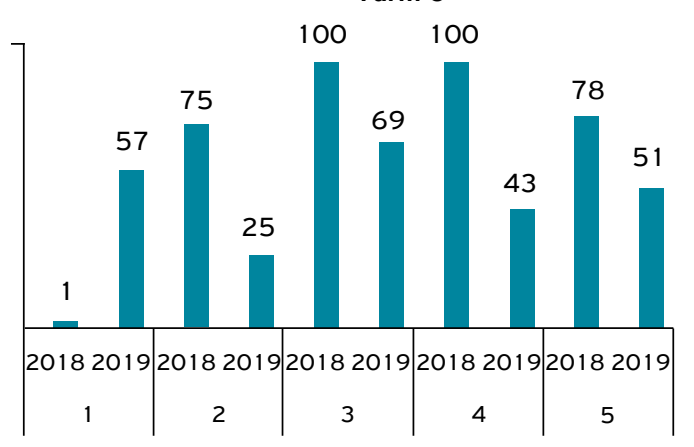

Farm B

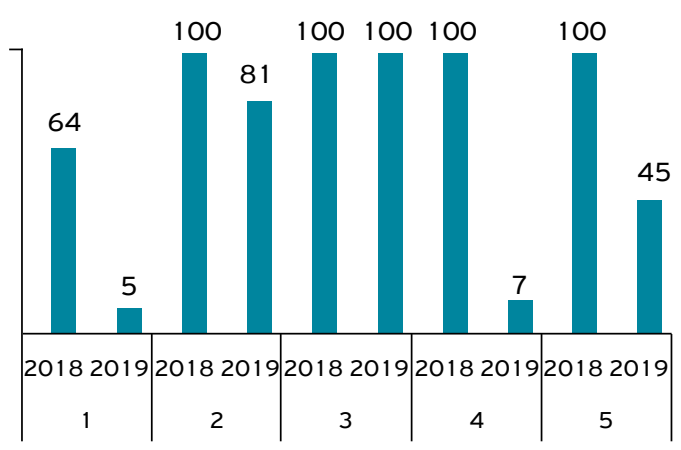

Farm D

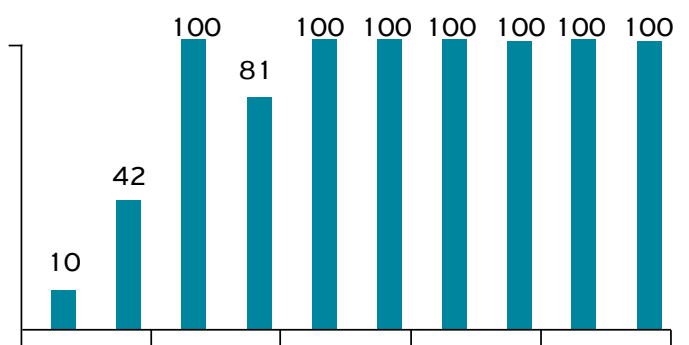

$2018201920182019 \mid 201820192018201920182019$

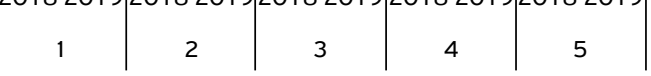

Farm F

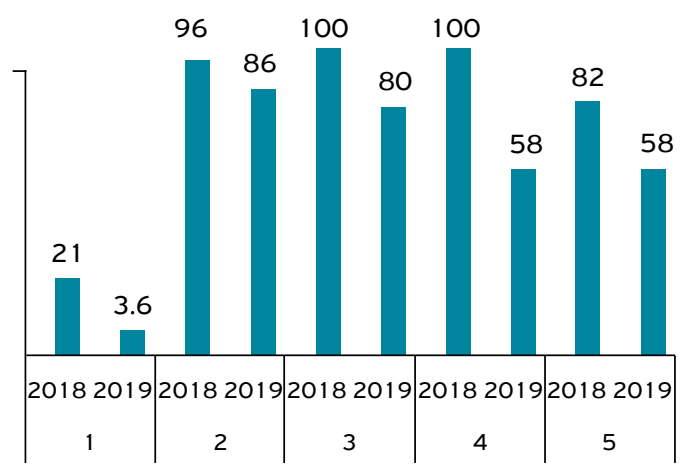

Farm H

100100100

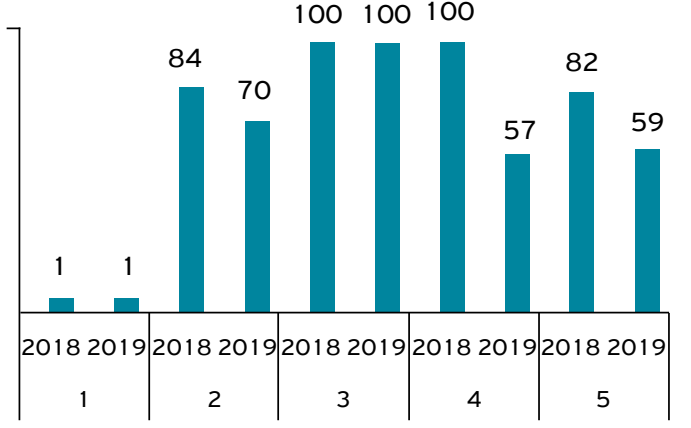

Figure 1. Percentage mean efficacy of five acaricides on samples of the tick Rhipicephalus microplus from eight farms (A-H) in the São Pedro region of the state of São Paulo, in 2018 and 2019.

Note. 1: deltamethrin; 2: amitraz; 3: cypermethrin + chlorpyrifos + citronella; 4: cypermethrin + chlorpyrifos + fenthion; 5: cypermethrin + chlorpyrifos + piperonyl butoxide. 
Table 1. Mean percentage efficacy of acaricides on samples of the tick Rhipicephalus microplus from fifteen farms in the São Pedro region of the state of São Paulo, in 2018 and 2019.

\begin{tabular}{|c|c|c|c|c|c|c|c|c|c|c|c|c|c|c|c|c|c|c|}
\hline \multirow{2}{*}{ Farm } & \multicolumn{2}{|c|}{1} & \multicolumn{2}{|c|}{2} & \multicolumn{2}{|c|}{3} & \multicolumn{2}{|c|}{4} & \multicolumn{2}{|c|}{5} & \multicolumn{2}{|c|}{6} & \multicolumn{2}{|c|}{7} & \multicolumn{2}{|c|}{8} & \multicolumn{2}{|c|}{9} \\
\hline & $\frac{\infty}{\delta}$ & $\frac{\pi}{2}$ & $\frac{\infty}{\infty}$ & $\frac{a}{\delta}$ & $\frac{\infty}{\sim}$ & $\frac{a}{\delta}$ & $\frac{\infty}{\delta}$ & $\frac{9}{2}$ & $\frac{\infty}{\sim}$ & $\frac{\pi}{2}$ & $\frac{\infty}{\delta}$ & $\frac{9}{2}$ & $\frac{\infty}{\delta}$ & $\frac{a}{\delta}$ & $\frac{\infty}{\infty}$ & $\frac{0}{2}$ & $\frac{\infty}{\delta}$ & $\frac{a}{\delta}$ \\
\hline A & 1 & 35 & 82 & 87 & 100 & 100 & 100 & 98 & 100 & 59 & 100 & - & - & 67 & - & 100 & - & 70 \\
\hline B & 64 & 5 & 100 & 81 & 100 & 100 & 100 & 7 & 100 & 45 & 100 & - & - & 7 & - & 100 & - & 72 \\
\hline C & 53 & 13 & 51 & 93 & 100 & 73 & 100 & 100 & 100 & 87 & 100 & - & - & 19 & - & 100 & - & 52 \\
\hline D & 10 & 42 & 100 & 50 & 100 & 100 & 100 & 100 & 100 & 100 & 100 & - & - & 64 & - & 100 & - & 41 \\
\hline$E$ & 82 & 18 & 88 & 80 & 100 & 100 & 100 & 100 & 91 & 73 & 100 & - & - & 66 & - & 100 & - & 36 \\
\hline$F$ & 21 & 3.6 & 96 & 86 & 100 & 80 & 100 & 58 & 82 & 58 & 100 & - & - & 52 & - & 89 & - & 28 \\
\hline G & 1 & 57 & 75 & 25 & 100 & 69 & 100 & 43 & 78 & 51 & 100 & - & - & 49 & - & 96 & - & 59 \\
\hline $\mathrm{H}$ & 1 & 1 & 84 & 70 & 100 & 100 & 100 & 57 & 82 & 59 & 100 & - & - & 25 & - & 100 & - & 10 \\
\hline I & 1 & - & 7 & - & 92 & - & 100 & - & 82 & - & 100 & - & - & - & - & - & - & - \\
\hline $\mathrm{J}$ & 8 & - & 100 & - & 100 & - & 100 & - & 1 & - & 100 & - & - & - & - & - & - & - \\
\hline L & 35 & - & 95 & - & 100 & - & 100 & - & 87 & - & 100 & - & - & - & - & - & - & - \\
\hline M & 3 & - & 17 & - & 100 & - & 100 & - & 100 & - & 100 & - & - & - & - & - & - & - \\
\hline $\mathrm{N}$ & 24 & - & 95 & - & 100 & - & 100 & - & 77 & - & 100 & - & - & - & - & - & - & - \\
\hline 0 & - & 18 & - & 100 & - & 56 & - & 100 & - & 83 & - & - & - & 100 & - & 100 & - & 67 \\
\hline$P$ & - & 22 & - & 100 & - & 39 & - & 100 & - & 100 & - & - & - & 9 & - & 100 & - & 46 \\
\hline $\begin{array}{l}\text { MEAN } \\
(\mathrm{A}-\mathrm{H})\end{array}$ & 29.1 & 21.8 & 84.5 & 71.5 & 100 & 90.3 & 100 & 70.4 & 91.6 & 66.5 & - & - & - & - & - & - & - & - \\
\hline $\mathrm{SD}(\mathrm{A}-\mathrm{H})$ & 32.5 & 20.6 & 16.2 & 23 & 0 & 13.8 & 0 & 34.8 & 9.7 & 18.8 & - & - & - & - & - & - & - & - \\
\hline $\begin{array}{l}\text { MEAN } \\
\text { (general) }\end{array}$ & 23.4 & 21.5 & 76.2 & 77.2 & 99.4 & 81.7 & 100 & 76.3 & 83.1 & 71.5 & 100 & - & - & 45.8 & - & 98.5 & - & 48.1 \\
\hline $\begin{array}{l}\text { SD } \\
\text { (general) }\end{array}$ & 27.3 & 18.2 & 31.6 & 23.6 & 2.2 & 22.1 & 0 & 33.2 & 26.3 & 20 & 0 & - & - & 30.2 & - & 3.6 & - & 20 \\
\hline
\end{tabular}

1: deltamethrin; 2: amitraz; 3: cypermethrin + chlorpyrifos + citronella; 4: cypermethrin + chlorpyrifos + fenthion; 5: cypermethrin + chlorpyrifos + piperonyl butoxide; 6 : dichlorvos + chlorpyrifos; 7 : cypermethrin; 8 : chlorfenvinphos + dichlorvos; 9 : ivermectin.

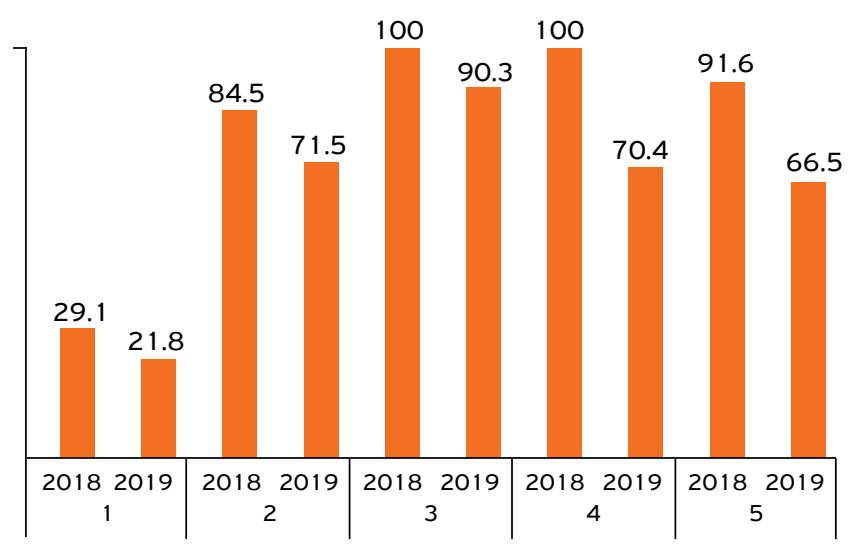

Figure 2. Percentage mean efficacy of five acaricides on samples of the tick Rhipicephalus microplus from farms in the São Pedro region of the state of São Paulo, in 2018 and 2019.

Note. 1: deltamethrin; 2: amitraz; 3: cypermethrin + chlorpyrifos + citronella; 4: cypermethrin + chlorpyrifos + fenthion; 5: cypermethrin + chlorpyrifos + piperonyl butoxide.

Overall, four acaricides presented mean efficacy greater than $89 \%$, among which two were associations of PI+OF and two were associations of OF+OF. Deltamethrin, cypermethrin and ivermectin presented mean efficacy of less than $50 \%$. The standard deviations in seven products ranged from 17 to 30 (Fig. 3). 


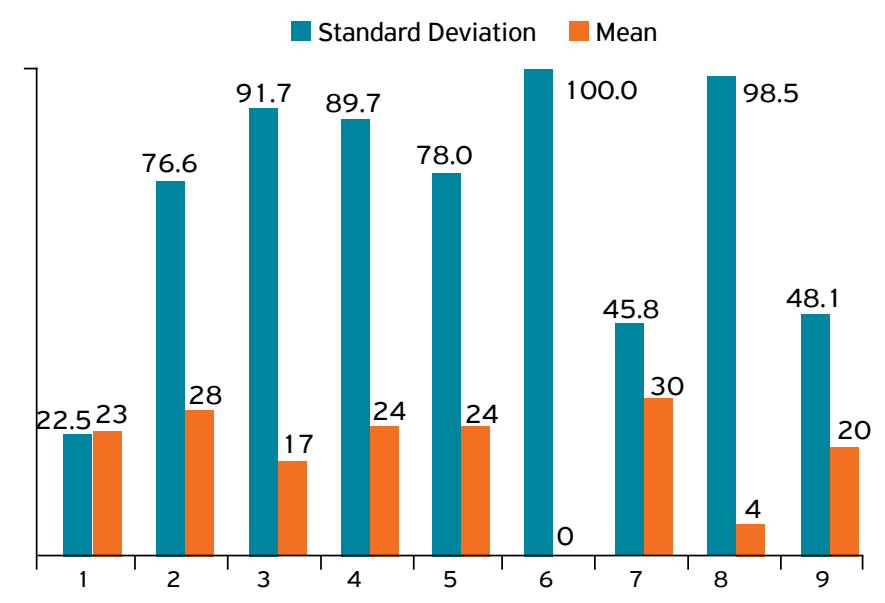

Figure 3. Percentage mean efficacy and standard deviation of nine acaricides on samples of the tick Rhipicephalus microplus from farms in the São Pedro region of the state of São Paulo.

Note. 1: deltamethrin; 2: amitraz; 3: cypermethrin + chlorpyrifos + citronella; 4: cypermethrin + chlorpyrifos + fenthion; 5: cypermethrin + chlorpyrifos + piperonyl butoxide; 6: dichlorvos + chlorpyrifos; 7: cypermethrin; 8: chlorfenvinphos + dichlorvos; 9: ivermectin.

In the bioassays using the LPT (Tables 3 and 4) all samples showed resistance to diazinon. Farm Q had the lowest resistance factor (2.66) and two farms ( $\mathrm{D}$ and $\mathrm{O}$ ) jointly had the highest factor (23). Only farm $\mathrm{D}$ presented a resistance factor (1.58) to cypermethrin.

\section{DISCUSSION}

Agricultural extension consists of taking scientific and technical knowledge to farmers in accessible language and is a task that is mainly the responsibility of government bodies. It has great importance because it is reflected in improved public health and growth of the Brazilian agricultural and livestock sector. The presentations on cattle ticks that were made to farmers in the municipality of Águas de São Pedro, before the bioassays were performed and afterward, with the results from the tests, were very valuable for both the technicians involved and for the farmers. From among the various products tests, each farm owner was able to ascertain which acaricides were most suitable for use on their herd and what the correct strategy for the treatment would be. This study demonstrated that the efficacy of a given agent could diminish from one year to the next and that monitoring of this using in vitro immersion tests is an important aid in achieving correct control over ticks.

HIGA et al. (2015) reported that the states of São Paulo and Mato Grosso do Sul presented similar resistance status, i.e., ticks were resistant to the same classes of active agents: organophosphates, pyrethroids, amidines, fipronil and associations between organophosphates and pyrethroids. The data obtained in the present study corroborate their findings.

The efficacy results from the present study showed that seven of the nine products tested (Fig. 2) had large standard deviations. These values demonstrate the sensitivity profiles for the populations of each farm, consequent to their histories of acaricide use. The mean efficacy for pyrethroids was $45 \%$ but there were some farms with $100 \%$ efficacy for cypermethrin. Similar results were found by HIGA et al. (2016) in an analysis on ticks on farms in Mato Grosso do Sul.

The resistance factor regarding cypermethrin that was present on just one of the five farms analyzed raises the possibility that the commercial products were of low quality.

Although organophosphates and associations of agents that included organophosphates were shown to be efficient in relation to other products, it is known that the development of resistance to organophosphates occurs over a seven to eight generations to obtain a homozygous resistant tick (FOIL et al., 2004). The resistance to diazinon that was observed on five farms, despite its efficacy in the in vitro immersion test, is a situation of concern.

Resistance to ivermectin was first reported in the state of São Paulo in 2006, in ticks from farms in the Paraíba Valley region, in a study by KLAFKE et al. (2006). Accelerated resistance to ivermectin may have arisen through the use of this product for controlling both endoparasites and ectoparasites, and because this is a chemical group that has long persistence.

In a review on resistance to acaricides in Brazil, published by HIGA et al. (2015), amitraz presented varying levels of resistance in 13 states, including São Paulo. In the present study, this active agent showed mean efficacy of close to 80\% (Fig. 3). Therefore, although it is well established that resistance to amitraz is present, it is lower than that of other products such as pyrethroids and macrocyclic lactones. Thus, it may still be an important tool for tick control. 


\section{CONCLUSION}

Considering all the factors involved in achieving successful control over cattle ticks, the present study demonstrates that the important points that need to be implemented relate directly to using control strategies based on providing direct assistance to farmers and diagnosing the sensitivity of the tick population.

\section{AUTHORS' CONTRIBUTIONS}

Conceptualization: Roma Junior, L.C.; Mendes, M.C. Data curation: Duarte, F. C.; Roma Junior, L.C.; Santos, M.L.; Fiorini, L.C.; Formal analysis: Duarte, F. C.; Roma Junior, L.C.; Funding acquisition: Roma Junior, L.C.; Investigation: Duarte, F. C.; Santos, M.L.; Fiorini, L.C.; Methodology: Roma Junior, L.C.; Santos, M.L.; Project administration: Roma Junior, L.C.; Resources: Duarte, F. C.; Supervision: Roma Junior, L.C.; Validation: Roma Junior, L.C.; Writing - original draft: Duarte, F. C.; Roma Junior, L.C.; Santos, M.L.; Fiorini, L.C.; Writing - review \& editing: Duarte, F. C.; Roma Junior, L.C.; Santos, M.L.; Fiorini, L.C.

\section{AVAILABILITY OF DATA AND MATERIAL}

All data generated or analyzed during this study are included in this published article.

\section{FUNDING}

Coordenação de Aperfeiçoamento de Pessoal de Nível Superior https://doi.org/10.13039/501100002322

Finance Code 001

Fundação de Desenvolvimento da Pesquisa do Agronegócio.

\section{CONFLICTS OF INTEREST}

All authors declare that they have no conflict of interest.

\section{ETHICAL APPROVAL}

Not applicable.

\section{ACKNOWLEDGEMENTS}

This study was partially granted by CAPES. The authors are grateful for the collaboration of Mauricio Perissinotto, responsible for the Rural Development Office of Piracicaba of the Sustainable Rural Development Coordination (CDRS/CATI).

\section{REFERENCES}

ARAÚJO, R.T. A política nacional de assistência técnica e extensão rural (PNATER) e o novo perfil profissional do médico veterinário. Ensaios e Ciência, Londrina, v.5, n.5, p.96-98, 2007.

BAFFI, M.A.; SOUZA, G.R.L.; SOUSA, C.S.; CERON, C.R.; BONETTI, A.M. Esterase enzymes involved in pyrethroid and organophosphate resistance in a Brazilian population of Riphicephallus (Boophilus) microplus (Acari, Ixodidae). Molecular and Biochemical Parasitology, Melbourne, v.160, n.1, p.70-73, 2008. https://doi.org/10.1016/j.molbiopara.2008.03.009

CEPAGRI - Centro de Pesquisas Meteorológicas e Climáticas Aplicadas à Agricultura. Clima dos Municípios Paulistas. Campinas: Universidade de Campinas, 2018. Available from: http://www.ciiagro.org.br/atemporal. Access on: 12 Mar. 2018.

COSSÍO-BAYÚGAR, R.; MARTÍNEZ-IBAÑEZ, F.; AGUILAR-DÍAZ, H.; MIRANDA-MIRANDA, E. Pyrethroid acaricide resistance is proportional to P-450 cytochrome oxidase expression in the cattle tick Rhipicephalus microplus. BioMed Research International, London, v.2018, 8292465, 2018. https://doi.org/10.1155/2018/8292465

DRUMMOND, R.O.; ERNST, S.E.; TREVINO, J.L.; GLADNEY, W.J.; GRAHAM, O.H. Boophilus annulatus and B. microplus: Laboratory tests of insecticides. Journal of Economic Entomology, Oxford, v.66, n.1, p.130-133, 1973. https://doi.org/10.1093/jee/66.1.130

FEYEREISEN, R.; DERMAUW, W.; VAN LEEUWEN, T. Genotype to phenotype, the molecular and physiological dimensions of resistance in arthropods. Pesticide Biochemistry and Physiology, Amherst, v.121, p.61-77, 2015. https://doi.org/10.1016/j.pestbp.2015.01.004 
FOIL, L.D. et al. Factors that influence the prevalence of acaricide resistance and tick-borne diseases. Veterinary Parasitology, Canterbury, v.125, n.1-2, p.163-181, 2004. https://doi.org/10.1016/j.vetpar.2004.05.012

GASPAR, E.B., SACCO, A.M.S., BENAVIDES, M.V.; TRENTIN, G. Medidas para controle de tristeza parasitária bovina (Comunicado Técnico 99). Bagé: Embrapa Pecuária Sul, 2018. Available from: https://ainfo.cnptia.embrapa.br/digital/bitstream/item/179466/1/ COMUNICADO-TECNICO-99.pdf. Access on: 15 Mar. 2018.

GRISI, L.; LEITE, R.C.; MARTINS, J.R. de S.; BARROS, A.T.M. de; ANDREOTTI, R.; CANÇADO, P.H.D.; LEÓN, A.A.P.; PEREIRA, J.B.; VILLELA, H.S. Reassessment of the potencial economic impact of cattle parasites in Brazil. Revista Brasileira de Parasitologia Veterinária, Jaboticabal, v.23, n.2, p.150-156, 2014. https://doi.org/10.1590/S1984-29612014042

GUGLIELMONE, A.A.; ROBBINS, R.G.; APANASKEVICH, D.A.; PETNEY, T.N.; ESTRADA-PEÑA., A.; HORAK, I.G.; SHAO, R. BARKER, S.C. The argasidae, ixodidae and nuttalliellidae (Acari: Ixodida) of the world: A list of valid species names. Zootaxa, Auckland, v.2528, n.1, p.1-28, 2010. https://doi.org/10.11646/zootaxa.2528.1.1

GUGLIELMONE, A.A.; NAVA, S. Names for Ixodidae (acari:Ixodoidea): Valid, synonyms, incertae sedis, nomina dúbia, nomina nuda, lapsus, incorrect and suppressed names-with notes on confusions and misidentifications. Zootaxa, Auckland, v.3767, n.1, p.001-256, 2014. https://doi.org/10.11646/zootaxa.3767.1.1

HEMINGWAY, J.; HAWKES, N.J.; McCARROLL, R.H. The molecular basis of insecticide resistance in mosquitoes. Insect Biochemistry and Molecular Biology, Ceske Budejovice, v.34, n.7, p.653-665, 2004. https://doi.org/10.1016/j.ibmb.2004.03.018

HIGA, L. de O.S.; GARCIA, M.V.; BARROS, J.C.; KOLLER, W.W.; ANDREOTTI, R. Acaricide resistance status of the Rhipicephalus microplus in Brazil: A literature overview. Medicinal Chemistry, Nashville, v.5, n.7, p.326-333, 2015. https://doi.org/10.4172/2161-0444.1000281

HIGA, L.O.S.; GARCIA, M.V.; BARROS, J.C.; KOLLER, W.W.; ANDREOTTI, R. Evaluation of Rhipicephalus (Boophilus) microplus (Acari: Ixodidae) resistance to different acaricide formulations using samples from Brazilian properties. Revista Brasileira de Parasitologia Veterinária, Jaboticabal, v.25, n.2, p.163-171, 2016. https://doi.org/10.1590/S1984-29612016026

KLAFKE, G.M.; SABATINI, G.A.; ALBUQUERQUE, T.A.; MARTINS, J.R.; KEMP, D.H.; MILLER, R.J.; SCHUMAKER, T.T.S. Larval immersion tests with ivermectin in populations of the cattle tick Rhipicephalus (Boophilus) microplus (Acari: Ixodidae) from state of São Paulo, Brazil. Veterinary Parasitology, Canterbury, v.142, n.3-4, p.386-390, 2006. https://doi.org/10.1016/j.vetpar.2006.07.001

KLAFKE, G. et al. Multiple resistance to acaricides in field populations of Rhipicephalus microplus from Rio Grande do Sul state, southern Brazil. Ticks and Tick-borne Diseases, Berlin, v.8, n.1, p.73-80, 2017. https://doi.org/10.1016/j.ttbdis.2016.09.019

KOLLER, W.W.; HIGA, L.O.S.; ZIMMERMANN, N.P.; OSHIRO, L.M.; ANDREOTTI, R. Resistência dos carrapatos aos acaricidas. In: ANDREOTTI, R.; GARCIA, M. V.; KOLLER, W.W. (ed). Carrapatos na cadeia produtiva de bovinos. Campo Grande: Embrapa Gado de Corte, 2019. Available from: https://ainfo.cnptia.embrapa.br/digital/bitstream/item/194277/1/Resistencia-dos-carrapatos-aos-acaricidas. pdf. Access on: 15 Mar. 2018.

KÖPPEN, W.; GEIGER, R. Die klimate der Erde. Gotha: Justus Perthes, 1928.

LE GALL, V.L.; KLAFKE, G.M.; TORRES, T.T. Detoxification mechanisms involved in ivermectin resistance in the cattle tick, Rhipicephalus (Boophilus) microplus. Scientific Reports, London, v.8, e12401, 2018. https://doi.org/10.1038/s41598-018-30907-7

LEORA SOFTWARE. POLO-PC: A user's guide to probit or logit analysis. Berkely: LeOra Software, 1987.

MENDES, M.C., SILVA, M.X.; BRACCO, J.E. Teste bioquímico para determinar a resistência de duas cepas do carrapato Boophilus microplus (Canestrini, 1887). Revista Brasileira de Parasitologia Veterinária, Jaboticabal, v.10, n.2, p.61-65, 2001.

PETTAN, K.B. As Inter-relações pesquisa, ensino e extensão. In: CASTRO, C.E.F.; BULISANI, E.A.; PETTAN, K.B.; CARBONELL, S.A.M.; MAIA, M.S.D. (ed.). Pontes para o futuro. Campinas: Consepa, 2005. p.49-64. 
RECK, J.; MARKS, F.S.; RODRIGUES, R.O.; SOUZA, U.A.; WEBSTER, A.; LEITE, R.C.; GONZALES, J.C.; KLAFKE, G.M.; MARTINS, J.R. Does Rhipicephalus microplus tick infestation increase the risk for myiasis caused by Cochliomyia hominivorax in cattle? Preventive Veterinary Medicine, Berlin, v.113, n.1, p.59-62, 2014. https://doi.org/10.1016/j.prevetmed.2013.10.006

ROSARIO-CRUZ, R.; ALMAZAN, C.; MILLER, R.J.; DOMINGUEZ-GARCIA, D.I.; HERNANDEZ-ORTIZ, J.F. Genetics basis and impact of tick acaricide resistance. Frontiers in Bioscience-Landmark, Singapore, v.14, n.7, p.2657-2665, 2009. https://doi.org/10.2741/3403 